\title{
Autopsy and premortem diagnostic discrepancy review in an Irish tertiary PICU.
}

Mark O'Rahelly ( $\square$ markorahelly@gmail.com )

Our Lady's Hospital Crumlin: Children's Health Ireland at Crumlin https://orcid.org/0000-0003-11823363

Michael McDermott

Children's Health Ireland at Crumlin

Martina Healy

Children's Health Ireland at Crumlin

\section{Research Article}

Keywords: Paediatric, ICU, Postmortem, Goldman, Discrepancy

Posted Date: April 15th, 2021

DOI: https://doi.org/10.21203/rs.3.rs-407612/v1

License: (c) (i) This work is licensed under a Creative Commons Attribution 4.0 International License. Read Full License 


\section{Abstract}

Objective: 1) Review ante- and post-mortem diagnoses and assign a Goldman error classification. 2) Establish autopsy rates.

Design: A retrospective analysis of autopsies performed on patients who died in Paediatric intensive care unit (PICU) between November 13th 2012 and October 31st 2018. We reviewed medical and autopsy data of all patients and Goldman classification of discrepancy between ante- and post-mortem diagnoses was assigned.

Setting: Tertiary PICU.

Patients: All patients that died in PICU within the designated timeframe.

Interventions: Goldman error classification assignment.

Measurements and main results: 396 deaths occurred in PICU from 8,329 (4.75\%) admissions. 99 (25\%) had an autopsy, 75 required by the coroner. All were included in the study. Fifty-three were male and 46 females. Fifty-three patients were transfers from external hospitals, 46 from our centre. Forty-one were neonates, 32 were $<1$ year of age, and 26 were $>1$ year of age. Median length of stay was 3 days.

Eighteen were post cardiac surgery, and three post cardiac catheter procedure. Major diagnostic errors (Class I/II) were identified in 14 (14.1\%), 2 (2\%) Class I, and 12 (12.1\%) were Class II errors. Class III and IV errors occurred in $28(28.2 \%)$ patients. Complete concordance (Class V) occurred in 57 (57.5\%) cases.

Conclusion: The autopsy rate and the diagnostic discrepancy rate within our PICU is comparable to those previously reported. Our findings show the continuing value of autopsy in determining cause of death and providing greater diagnostic clarity. Given their value, post-mortem examinations, where indicated, should be considered part of a physician's duty of care to families and future patients.

\section{Highlights}

\section{What is known:}

- Major diagnostic discrepancies (Class I/II) in PICU have been reported at 20.2\%. ${ }^{(10)}$

- PICU autopsy rates have varied from 36-67\% since 1994 with most recently reported rates in 2018 being $36 \%{ }^{(6-9)}$

\section{What is new:}

- We report an Irish PICU major diagnostic discrepancy (Class I/II) rates of $14.1 \%$ contributing further to reported discrepancy rates in PICU literature to date. 
- This study contributes the Irish PICU post mortem rate in a tertiary centre which was $25 \%$ over an almost six-year period.

\section{Introduction}

Our study took place in a tertiary referral paediatric intensive care unit (PICU) which cares for an average of 1,044 admissions per year over 6 years from November 13th 2012 and October 31st 2018. The unit accepts patients ranging from extreme prematurity to 16 year. It is one of only two PICUs in the Republic of Ireland and comprises a 15 bed general intensive care unit (ICU) and an 8 bed cardiac ICU. Extracorporeal Life Support (ECLS) is available in support of the cardiac program.

Given the severity of illness managed in a PICU, deaths are inevitable. Indeed, the overwhelming majority of deaths amongst in-patients in our institution now occur in the PICU. Due to the complex nature of this cohort of patients, identifying all those factors that have contributed to a patient's death may prove challenging, as may arriving at an unambiguous single designation for the cause of death.

Credible medical post mortem examinations were first performed over 300 years ago and they continue to make a significant contribution in supporting legal, forensic, audit, clinical governance, teaching and research activities. [1] Despite advances in modern imaging and other modalities, diagnostic discrepancies are still identified at post mortem. Post mortem examination remains a particularly valuable tool for the identification and evaluation of pathologic processes in complex patients. [2]

The Goldman criteria - first described in 1983 - is a means of classifying a discrepancy occurring between ante- and post mortem diagnosis and is outlined in Table 1. [3]

\section{Table 1.}

\section{Goldman Classification}

\begin{tabular}{|ll|}
\hline $\begin{array}{l}\text { Class } \\
\text { I }\end{array}$ & $\begin{array}{l}\text { Missed major diagnosis with a potential adverse impact on survival that would have } \\
\text { changed management }\end{array}$ \\
\hline $\begin{array}{l}\text { Class } \\
\text { Class } \\
\text { III }\end{array}$ & $\begin{array}{l}\text { Missed major diagnosis with no potential impact on survival that would not have changed } \\
\text { therapy }\end{array}$ \\
$\begin{array}{l}\text { Class } \\
\text { IV }\end{array}$ & Other missed minor diagnosis \\
\hline $\begin{array}{l}\text { Class } \\
\text { V }\end{array}$ & Absolute agreement \\
\hline
\end{tabular}


The primary aim of this study was to compare both the pre mortem and post mortem diagnoses assigning a Goldman classification to each individual case. The second aim was to review our centre's data and to determine the number of post-mortem examinations performed and compare that against our demographic data (number of admissions, crude mortality rate etc.).

\section{Materials And Methods}

We undertook a retrospective analysis of patients who died in the PICU in Children's Health Ireland at Crumlin and subsequently had an autopsy performed. We included all patients admitted from the introduction of electronic healthcare records - which came into effect in the PICU in November 2012 - until October 2018. A list of referral sources and all patient data originating from the PICU was accessed for the period. A total of 100 patients met inclusion criteria. Electronic and paper based medical notes were reviewed and all demographic and clinical data were collected, including clinical diagnoses recorded at the time of death. This information was then cross referenced with the autopsy reports retrieved from the pathology department database. One case was excluded as due to the medicolegal nature of the case we did not have access to the post-mortem outcome. This left 99 cases to be analysed.

The information gathered included age, gestational age, if the patient had surgery, length of stay, referral source, underlying medical conditions, limitations of supportive care documented, immediate proximate cause of death, antemortem diagnosis and post mortem findings and diagnosis. This information was then examined and discussed by a consultant paediatric intensivist, a consultant paediatric pathologist and an ICU senior registrar. This process resulted in the assignment of an agreed Goldman classification for each case Table 1. All Class V classifications were assigned by the consultant pathologist at the time of data entry if complete concordance of diagnoses was noted. For all other cases, the full group reviewed all ante-mortem diagnostic data and then reviewed post-mortem findings together in order to arrive at a consensus. This data then permitted the prevalence and pattern of diagnostic discrepancies to be described for our patient cohort.

\section{Results}

Over the 6-year period covered by the study, there were 8,329 admissions to PICU with 4,578 males (54.9\%) and 3,751 females (45\%). Of these admissions, 2,302 were neonates (27.6\%) and 2,431 were between 28 days and 1 year of age (29.1\%). There were 6,349 admissions from within our own institution (76.2\%) and the remaining 1,980 were referred from external centres (23.8\%). There were 396 PICU deaths during this period giving a mortality rate of $4.75 \%$. Of the 396 deaths, $99(25 \%)$ had an autopsy performed. Table 2. shows the patient demographics of all admissions and autopsies over the study period. 
Table 2

\begin{tabular}{|lll|}
\hline Characteristic & All PICU Admissions & PICU Autopsy Cohort \\
\hline Number $(\mathrm{n})$ & 8329 & 99 \\
\hline Sex (male) & $4578(54.9 \%)$ & $53(53.5 \%)$ \\
\hline Age & & \\
\hline Neonates & $2302(27.6 \%)$ & $41(41.4 \%)$ \\
\hline$<1$ year excluding neonates & $2431(29.1 \%)$ & $32(32.3 \%)$ \\
\hline Median Length of stay (days) & 4 & 3 \\
\hline Admission source & & \\
\hline Same hospital & $6349(76.2 \%)$ & $46(46.4 \%)$ \\
\hline External hospital & $1980(23.7 \%)$ & $53(53.5 \%)$ \\
\hline Post-Surgery & $3729(44.7 \%)$ & $24(24.2 \%)$ \\
\hline
\end{tabular}

The mortality autopsy rate by age and admission source are summarised in Fig. 1 .

Of the patients undergoing post-mortem examination, 53 were male (53.5\%) and 46 females (46.5\%). External hospitals referred 53 of these patients, and 46 came from within our own hospital. Forty-one of the patients were neonates, 32 patients $>28$ days and $<1$ year of age and 26 patients $>1$ year of age. The median length of stay was 3 days. Seventy patients $(70.7 \%)$ had a pre-existing co morbidity diagnosed at the time of death. Twenty-four of the patients were post-operative: 18 post cardiac surgery, three post cardiac catheter procedure, and three post 'other' surgery. There were documented limitations of supportive care in place for 77 patients prior to their death in the ICU. Of the remaining patients, 21 died following delivery of conventional cardio-pulmonary resuscitation with one patient dying following discontinuation of extracorporeal resuscitation.

There was complete concordance between ante mortem and post-mortem diagnosis in $57(57.5 \%)$ of our patients, corresponding to a Goldman Class V designation ${ }^{1}$. Two (2\%) Class I discrepancies occurred: a post mortem diagnoses of anomalous coronary artery and an unsuspected T-cell leukaemia/lymphoma. Class II errors were identified in $12(12.1 \%)$ patients. More detail on these cases is outlined in Table 3. Class III accounted for 20 (20.2\%) of the cases and Class IV accounted for $8(8 \%)$. In the remaining case, we were unable to ascertain results for medico-legal reasons. 
Table 3

\begin{tabular}{|c|c|c|c|c|}
\hline Patient & Age & Ante mortem diagnosis & Post Mortem diagnosis & $\begin{array}{l}\text { Goldman } \\
\text { Classification }\end{array}$ \\
\hline $1(56)$ & $\begin{array}{l}12 \\
\text { years }\end{array}$ & $\begin{array}{l}\text { Cardiac arrest query } \\
\text { ventricular fibrillation due } \\
\text { to myocarditis }\end{array}$ & $\begin{array}{l}\text { Myocardial ischaemia due to } \\
\text { arrhythmia and anomalous } \\
\text { coronary artery, echo virus and } \\
\text { encephalitis }\end{array}$ & 1 \\
\hline $2(75)$ & $\begin{array}{l}12 \\
\text { years }\end{array}$ & $\begin{array}{l}\text { Haemophagocytic } \\
\text { lymphohistiocytosis with } \\
\text { possible pneumocystis } \\
\text { pneumonia infection }\end{array}$ & $\begin{array}{l}\text { Natural killer cell } \\
\text { leukaemia/Lymphoma }\end{array}$ & 1 \\
\hline $3(4)$ & $\begin{array}{l}13 \\
\text { years }\end{array}$ & $\begin{array}{l}\text { Renal disease, sickle cell, } \\
\text { cerebral oedema }\end{array}$ & $\begin{array}{l}\text { Systemic lupus erythematosus } \\
\text { (Renal, neural, nodal), } \\
\text { macrophage activation } \\
\text { syndrome. Pulmonary } \\
\text { aspergillus }\end{array}$ & 2 \\
\hline $4(7)$ & $\begin{array}{l}11 \\
\text { days }\end{array}$ & $\begin{array}{l}\text { Metabolic disorder causing } \\
\text { brain injury }\end{array}$ & Parechovirus encephalopathy & 2 \\
\hline $5(15)$ & 1 day & $\begin{array}{l}\text { Hypoxic brain injury due to } \\
\text { meconium aspiration and } \\
\text { large abdominal } \\
\text { arteriovenous } \\
\text { malformation }\end{array}$ & $\begin{array}{l}\text { Hypoxic brain injury due to } \\
\text { meconium aspiration, } \\
\text { extrahepatic biliary atresia, } \\
\text { hexokinase } 1 \text { deficiency }\end{array}$ & 2 \\
\hline $6(39)$ & $\begin{array}{l}5 \\
\text { months }\end{array}$ & $\begin{array}{l}\text { Out of hospital cardiac } \\
\text { arrest }\end{array}$ & $\begin{array}{l}\text { H1N1 myocarditis, pneumonitis } \\
\text { and hepatitis }\end{array}$ & 2 \\
\hline $7(44)$ & $\begin{array}{l}13 \\
\text { days }\end{array}$ & $\begin{array}{l}\text { Middle cerebral artery } \\
\text { (MCA) infarct secondary to } \\
\text { congenital heart disease } \\
\text { (CHD) }\end{array}$ & $\begin{array}{l}\text { MCA infarct secondary to CHD, } \\
\text { bronchopneumonia and } \\
\text { pulmonary lymphangiectasia }\end{array}$ & 2 \\
\hline $8(46)$ & $\begin{array}{l}4 \\
\text { months }\end{array}$ & $\begin{array}{l}\text { Pulmonary hypertension } \\
\text { secondary to } \\
\text { emphysematous lung } \\
\text { disease and CHD }\end{array}$ & $\begin{array}{l}\text { Respiratory failure secondary to } \\
\text { dysmaturity and diffuse } \\
\text { alveolar damage, } \\
\text { filamin A mutation, cardiac } \\
\text { valve dysplasia, pyloric } \\
\text { stenosis, ulcerative ileitis }\end{array}$ & 2 \\
\hline $9(51)$ & 1 day & $\begin{array}{l}\text { Ichthyosis, seizures, atrial } \\
\text { septal defect, patent ductus } \\
\text { arteriosus, } \\
\text { thrombocytopenia }\end{array}$ & $\begin{array}{l}\text { Cardiomyopathy secondary to } \\
\text { congenital glycosylation } \\
\text { disorder, ichthyosis }\end{array}$ & 2 \\
\hline $\begin{array}{l}10 \\
(55)\end{array}$ & $\begin{array}{l}42 \\
\text { days }\end{array}$ & $\begin{array}{l}\text { Pulmonary hypoplasia, } \\
\text { congenital nephrotic } \\
\text { syndrome }\end{array}$ & $\begin{array}{l}\text { Thromboembolism and } \\
\text { vasculopathy, myocardial } \\
\text { ischaemia }\end{array}$ & 2 \\
\hline $11(59)$ & $\begin{array}{l}11 \\
\text { years }\end{array}$ & $\begin{array}{l}\text { Idiopathic pulmonary } \\
\text { hypertension }\end{array}$ & Pulmonary Haemorrhage & 2 \\
\hline
\end{tabular}




\begin{tabular}{|lllll|}
\hline Patient & Age & Ante mortem diagnosis & Post Mortem diagnosis & $\begin{array}{l}\text { Goldman } \\
\text { Classification }\end{array}$ \\
\hline $\begin{array}{l}12 \\
(61)\end{array}$ & $\begin{array}{l}2.5 \\
\text { months }\end{array}$ & $\begin{array}{l}\text { Multiorgan failure due to } \\
\text { unknown inflammatory } \\
\text { process/vasculitis }\end{array}$ & Takayasu arteritis & 2 \\
\hline $\begin{array}{l}13 \\
(65)\end{array}$ & $\begin{array}{l}\text { Tardiac arrest secondary to } \\
\text { months }\end{array}$ & $\begin{array}{l}\text { Carpoxic brain injury, fetal } \\
\text { mucus plug vs foreign body }\end{array}$ & $\begin{array}{l}\text { Hydocardial fibroeleastosis } \\
\text { endion }\end{array}$ & 2 \\
\hline $\begin{array}{l}14 \\
(94)\end{array}$ & 3 days & $\begin{array}{l}\text { Dilated cardiomyopathy } \\
\text { and cardiac arrest }\end{array}$ & $\begin{array}{l}\text { Cardiomyopathy secondary to } \\
\text { mitochondrial disorder }\end{array}$ & 2 \\
\hline
\end{tabular}

\section{Discussion}

Throughout its long history, post-mortem examination has remained the gold standard against which any ante-mortem clinical diagnosis is compared. [4] It continues to play a central role in the forensic analysis of unnatural death as well as representing an important tool for medical audit, underpinning the clinical governance of hospital services. Autopsies also provide opportunities for the teaching of medical, nursing and allied health professionals, and continues to contribute towards research and the understanding of disease, as demonstrated most dramatically in the evaluations of recent deaths due to Covid-19 as caused by the novel coronavirus SARS-CoV-2. [5] In certain cases, it also provides additional diagnoses, as per our data, class I-IV contributed information in 42 cases $(42.4 \%)$ which was unknown prior to the post-mortem results.

The focus of this study was to ascertain the number of autopsies undertaken on patients dying in our paediatric intensive care unit, and to establish the contribution the autopsy made to the understanding of the patient's illness. The autopsy rate during the period of the study was $25 \%$ which is lower than that previously reported in the US at 36\%. [6] Autopsy rates have fallen in many parts of the world, with a relatively precipitous fall in consented autopsies in Ireland following public disquiet due to revelations of organ retention in 1999. Adappa et al reported lack of consent as the primary reason for the reduction in autopsy rates from the period 1994-1996 compared to 2001-2003. [7] In our institution, the autopsy rate fell by $40 \%$ in the period $2000-2002$ in part due to reluctance of families to give consent, and also in part by medical staff's reluctance to discuss the prospect with families given the public discussion at the time. The autopsy rate in our unit remained relatively stable throughout the study period, however the majority of these were performed under the direction of the coroner. Seventy-five cases (75\%) involved in our study underwent post-mortem after discussion with the coroner.

Whether legally directed or consented by families, it is important that autopsy rates remain at a sufficient level to permit detection of systemic errors in the performance of an institution. It is therefore vital that hospital staff continue to advocate for a high level of post mortem interrogation of deaths, so that they 
may be able to reassure the hospital authorities and users of the service that their service continues to provide an appropriate level of care.

To support physicians in pursuing this goal, it is important to acknowledge the limitations of clinical diagnosis. Although we applied an "error" classification tool to describe discrepancies between clinically derived diagnostic conclusions and autopsy findings, this should not be taken to mean that shortcomings in the care delivered have been identified. Rather, such new findings, merely serve to highlight the unique role this potent form of investigation plays in furthering our understanding of disease. Previous studies have shown that autopsies add new information in $23-47.5 \%$ of cases and previously reported major discrepancy rates amongst the paediatric age group have varied but remain approximately $20 \%$. [8-10] Our review identifies a major discrepancy in $14.1 \%$ of examinations, a figure derived from the combination of Class 1 and Class 2 errors. In part, this comparatively low figure may reflect the relatively high percentage of patients with congenital heart disease in which either detailed imaging or surgical intervention had been performed prior to the death. It may also reflect improvements in the quality of imaging and other diagnostic modalities which underlie secular decreasing discrepancy rates as published, in relation to both paediatric and adult ICU cohorts. [11-13]

However, even with these improvements and although many authors have discussed alternatives, we find it difficult to envisage a scenario in which it would be possible to entirely remove the need for postmortem examinations for the foreseeable future. A dry chart review following the death of a patient can often help opinions coalesce around a likely cause of death. Post-mortem cross sectional imaging with CT or MR can also provide critical information about the cause of death. Nonetheless, concordance rates with CT scanning are at best moderate (57.1-83.3\%). [14-17] In circumstances where imaging is helpful, it is often best used as a means of focusing subsequent invasive post-mortem examination which might potentially be limited to a biopsy of a region of interest rather than full body examination.

While not detracting from the principal finding that discrepancies remain a feature of post mortem examinations, it is appropriate to acknowledge some subjectivity in the application of the Goldman Error Classification system. The authors of this study had some lengthy conversations about many of the individual patients whose clinical care and autopsy findings were reviewed. Indeed, one of the conclusions of the study is the difficulty in applying a relatively rigid Goldman classification of errors to the complex setting of an intensive care unit in which patients frequently have multiple co-morbidities. Instead of identifying single discrepancies that were easily designated as one class or another, the conversations often revolved around the re-evaluation of the relative contribution of the multiple problems already known to afflict an individual patient. Thus, for example, a patient with known congenital heart disease, lung disease associated with prematurity and superimposed sepsis might, after a discussion of the clinical data and post-mortem findings, have a re-interpretation of the relative contributions each of these known findings made to the patient's ultimate demise. As such, even when not detecting a discrepancy per se, the autopsy process contributed to a change in the narrative given to the family by the hospital staff. 
The role autopsy plays in arriving at the most in-depth understanding of the factors contributing to death is central to the way post-mortem investigations are communicated in our institution. To facilitate this, where indicated, the pathologist meets with the family close to the time of death to discuss conducting a post mortem examination. This helps to facilitate questions the family may have regarding the procedure and ensures clarity about the post mortem process. This open discourse ensures clarity and consistency of information is imparted to the patient's family. [18] Each death in our Unit is discussed at a multidisciplinary morbidity and mortality meeting where all teams involved in the patients' care can attend. Post-mortem reports are presented at this multidisciplinary mortality review meeting. Care is discussed and evaluated and an agreed narrative conclusion reached. This considered opinion is then delivered to parents in face-to-face at follow-up, next-of-kin clinics. These afford parents an opportunity to ask questions about the findings and any aspects of care. [19] This integration of post-mortem results into Unit Morbidity and Mortality case discussion, as well as bereavement follow-up with the family, places the autopsy within a continuum of care offered to the patient and their family, rather than as a discrete exercise undertaken by a detached pathologist, and divorced from the patient and staff caring for them.

Our study had a number of limitations. It was retrospective, and although this was largely immaterial in relation to the post mortem finding, collection and evaluation of such clinical data as is pertinent, would be more easily and more comprehensively performed in a prospective fashion. The majority of post mortem exams reviewed were performed at the direction of the Coroner's office. This may limit the generalisability of our findings to exams performed on medical rather than legal grounds. Also assignment of Goldman classification was not blinded or undertaken by medical professionals unaffiliated with our centre. We do not believe these limitations detract from the central findings in this study.

\section{Conclusion}

In conclusion, our findings show that the autopsy rate at our centre is comparable to that in many other studies and is at a sufficient level to detect a proportion of systemic errors in care within our complex PICU environment. The autopsy continued to find a small but significant rate of discrepancy between the pre-mortem clinical interpretation of the cause of death and post-mortem findings. The Goldman classification can present some difficulties in its application due the user interpretation of the qualitative data. The classification still holds merit given its wide use and application in studies published to data allowing comparison between similar units. Furthermore, autopsies often provided information that permitted a more nuanced re-evaluation of the contribution of many known co-morbidities as well as identifying other associated anomalies unrelated to the cause of death, but which altered the discussion that ultimately took place between families and hospital staff.

\section{List Of Abbreviations}

PICU: Paediatric Intensive Care Unit 
ICU: Intensive Care Unit

ECLS: Extracorporeal Life Support

SARS-CoV-2: Severe Acute Respiratory Syndrome Coronavirus-2

CT: Computed tomography

MR: Magnetic resonance

\section{Declarations}

Funding: There was no funding provided for this study.

Conflicts of interest/Competing interests: The authors declare no competing interests.

Availability of data: Data can be shared upon reasonable request.

Code availability: N/a

\section{Author Contributions:}

$M O^{\prime} \mathrm{R}, \mathrm{MH}$ and $\mathrm{MMcD}$ all contributed towards the study design. MO'R collected data from PICU database and $\mathrm{MMCD}$ from the Pathology database. All three authors contributed equally towards the results and drafting of the manuscript.

Ethics approval: This study, REC reference GEN/879/20, was reviewed by the $\mathrm{CHI}$ at Crumlin Ethics Committee and publication of these Clinical Audit findings were approved.

Consent to participate: Not applicable.

Consent for publication: All authors consent to publication of the manuscript in the European Journal of Paediatrics, should the article be accepted by the Editor-in-chief upon completion of the refereeing process.

\section{References}

1. Dada MA, Ansari NA. Origins of .... the postmortem examination in diagnosis. J Clin Pathol 1996;49(12):965-6. http://dx.doi.org/10.1136/jcp.49.12.965

2. Roberts ISD, Benamore RE, Benbow EW, et al. Post-mortem imaging as an alternative to autopsy in the diagnosis of adult deaths: a validation study. Lancet 2012; 379:136-42. https://doi.org/10.1016/S0140-6736(11)61483-9

3. Goldman L, Sayson R, Robbins S, et al. The value of the autopsy in three medical eras. N Engl J Med 1983;308(17):1000-5. 
4. Burton JL, Underwood J. Clinical, educational, and epidemiological value of autopsy. The Lancet 2007; 369:1471-80. https://doi.org/10.1016/S0140-6736(07)60376-6

5. Menter T, Haslbauer JD, Nienhold R, et al. Post-mortem examination of COVID19 patients reveals diffuse alveolar damage with severe capillary congestion and variegated findings of lungs and other organs suggesting vascular dysfunction. Histopathology 2020; 77(2):198-209. https://doi.org/10.1111/his.14134

6. Basu S, Holubkov R, Dean JM, et al. PICU Autopsies: Rates, Patient Characteristics, and the Role of the Medical Examiner. Pediatr Crit Care Med 2018; 19(12):1137-45.

7. Adappa R, Paranjothy S, Roberts Z, et al. Perinatal and infant autopsy. Arch Dis Child Fetal Neonatal Ed 2007; 92(1): F49-50. http://dx.doi.org/10.1136/adc.2005.091447

8. von Dessauer B, Velozo L, Benavente $\mathrm{C}$, et al. Postmortem studies in the contemporary pediatric intensive care unit. Pediatr Crit Care Med 2011; 12(6):617-21.

9. Widmann R, Caduff R, Giudici L, et al. Value of postmortem studies in deceased neonatal and pediatric intensive care unit patients. Virchows Archiv 2016; 470(2):217-23. https://doi.org/10.1007/s00428-016-2056-0

10. Custer JW, Winters BD, Goode V, et al. Diagnostic errors in the pediatric and neonatal ICU: a systematic review. Pediatr Crit Care Med. 2015; 16(1):29-36

11. Podbregar M, Voga G, Krivec B, et al. Should we confirm our clinical diagnostic certainty by autopsies? Intensive Care Med 2001; 27(11):1750-5. https://doi.org/10.1007/s00134-001-1129-x

12. Sonderegger-Iseli K, Burger S, Muntwyler J, et al. Diagnostic errors in three medical eras: a necropsy study. Lancet 2000; 355:2027-31. https://doi.org/10.1016/S0140-6736(00)02349-7

13. Schwanda-Burger S, Moch $\mathrm{H}$, Muntwyler $\mathrm{J}$, et al. Diagnostic errors in the new millennium: a follow-up autopsy study. Mod Pathol 2012; 25(6):777-83. https://doi.org/10.1038/modpathol.2011.199

14. Krentz BV, Alamo L, Grimm J, et al. Performance of post-mortem CT compared to autopsy in children. Int J Legal Med 2016; 130(4):1089-99. https://doi.org/10.1007/s00414-016-1370-z

15. Noda Y, Yoshimura K, Tsuji S, et al. Postmortem computed tomography imaging in the investigation of nontraumatic death in infants and children. Biomed Res Int 2013:327903.

https://doi.org/10.1155/2013/327903

16. Sieswerda-Hoogendoorn T, Soerdjbalie-Maikoe V, de Bakker $\mathrm{H}$, et al. Postmortem CT compared to autopsy in children; concordance in a forensic setting. Int $J$ Legal Med 2014; 128(6):957-65. https://doi.org/10.1007/s00414-014-0964-6

17. Proisy M, Marchand AJ, Loget $P$, et al. Whole-body post-mortem computed tomography compared with autopsy in the investigation of unexpected death in infants and children. Eur Radio/ 2013; 23(6):1711-9. https://doi.org/10.1007/s00330-012-2738-1

18. McDermott M. The continuing decline of autopsies in clinical trials: is there any way back? Arch Dis Child Fetal Neonatal Ed 2004; 89(3): F198-9. http://dx.doi.org/10.1136/adc.2003.045609 
19. McDermott MB. Obtaining consent for autopsy. Bmj 2003; 327:804-6. https://doi.org/10.1136/bmj.327.7418.804

\section{Figures}

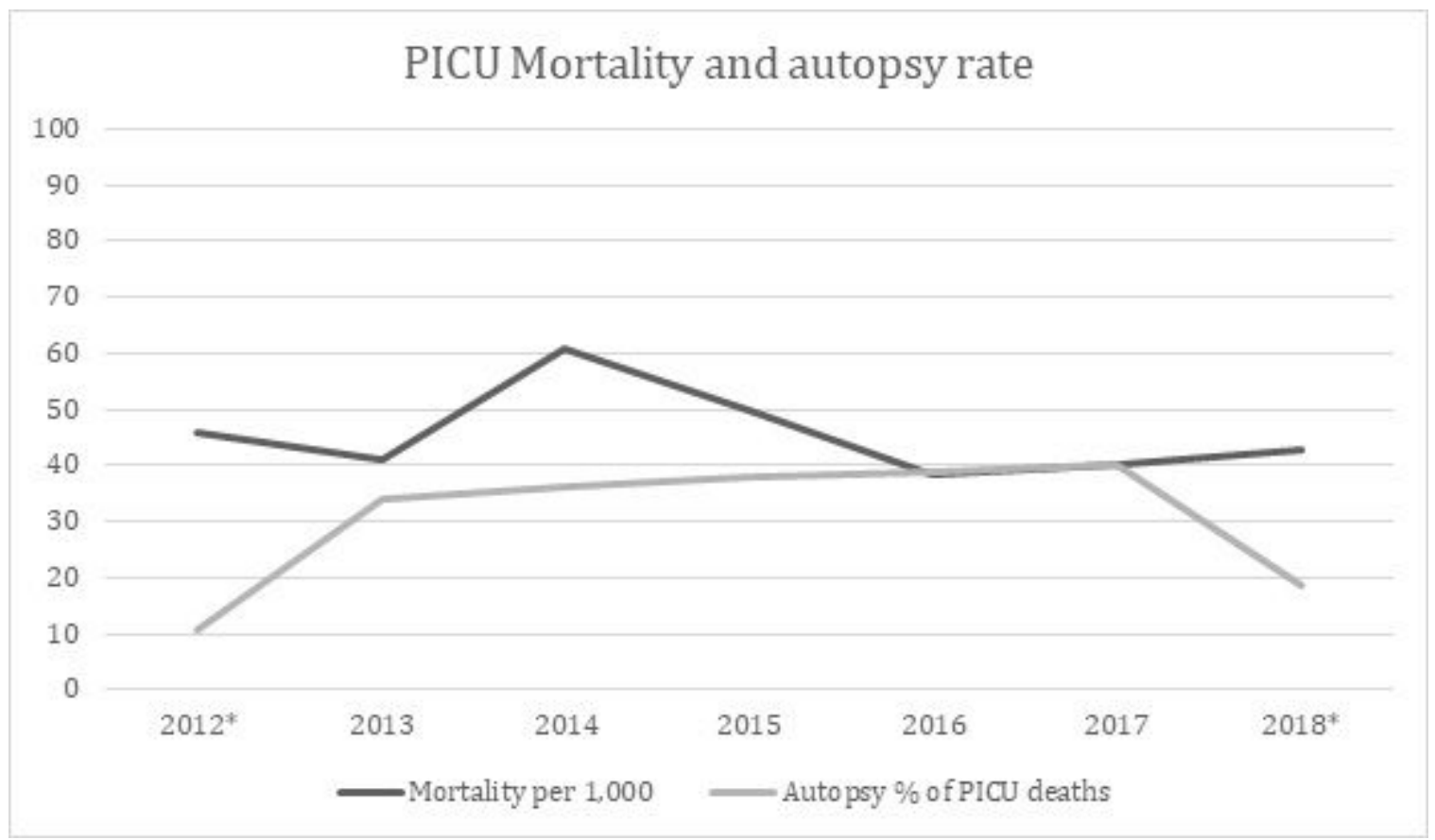

Figure 1

*incomplete datasets for indicated years 